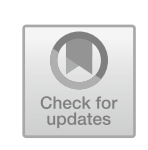

\title{
Stories of Inspiration: "Learning Is Beneficial to the Talent, Just as Grinding Can Make the Knife Sharp"
}

\section{"Work Like Farm CATtLE"}

Literary and artistic production is about arduous creation that does not allow even the slightest falsehood. None of the fine works that enjoy widespread popularity and enduring fame was created in an impatient or impetuous state of mind. They were all forged by the creators straining their heart and mind without seeking fortune. As the old saying goes, "To come up with an appropriate character, I lost several beards (because I like stroking my beard as I compose verses)" and "It cost me three years to compose these two lines. So every time I read them, the tears stream down my face." On the tombstone of Lu Yao, it says, "Work like farm cattle, and dedicate like the soil." Tolstoy also said, "If someone tells me I can write a novel in which I have no problem airing a view that I think is correct on all social issues, then such a novel will take me less than two hours. But if someone tells me that this novel will be read by children twenty years later, and it will even make them cry or laugh, or they will love life because of it, then I will devote my whole life and all my strength to this novel."

- Speech at the Opening Ceremony of the 10th Congress of the China Federation of Literary and Art Circles and the Ninth Congress of the Chinese Writers Association (November 30, 2016). 


\section{Commentary}

Throughout the ages, the great literary and artistic works have been based on accumulated strength, and their literary and artistic quality manifests their creators' inner enrichment. A work that is circulated for generations or is an eternal masterpiece must be created through perseverance, without hurry and haste, and it must cost all the creator's strength and energy. It can be said that staying calm and steady in work without distraction is an essential quality of all the literary and artistic masters who have been credited with universally praised works.

Jia Dao was a famous poet of the Tang Dynasty who had a painstaking style. In the middle-Tang Dynasty, the painstaking-style poets, typified by Meng Jiao and Jia Dao, held an extremely rigorous and serious attitude toward the creation of poetry and focused on weighing characters and deliberating about expressions. While composing the line "Birds nestle in the trees by the pond, a monk knocks at the door awash in the moon", Jia Dao deliberated whether to use the expression "knock" or "push" for a long time. He even made friends with Han Yu for the purpose of weighing the words, which led to the much-told story of "Jia Dao knocked and pushed." After finishing the poem Farewell to Monk Wuke, Jia Dao added a verselet as the annotation of the line "With his lonely silhouette being reflected in the pool, he rested on trees many times." The poet said, "It took me three years to compose these two lines. So every time I read them, the tears stream down my face. If the lines fail to gain the appreciation of my closest friends, I have no alternative but return to my mountainous hometown and live in seclusion." This annotation interprets his spirit of painstaking composition. Speaking of the painstaking style, there have been many more lines on this subject. For example, "To come up with an appropriate character, I lost several beards (because I like stroking my beard as I compose verses)" by Lu Yanrang; "What made you so thin since we did part? Did the versecomposing wring your heart?" by Li Bai in Joking with $\mathrm{Du} \mathrm{Fu}$; and "I like refining my verses, to the extent that the people read them and marvel at them" by Du Fu.

"Work like farm cattle, and be dedicated like the soil." This was the motto of Lu Yao, which also mirrored his personality and spirit. Lu Yao lived in an era when literary concepts such as the modernist school and stream of consciousness were all the rage, and literary novel forms and techniques emerged overwhelmingly; however, he insisted on the writing 
technique of traditional realism. He began The Ordinary World in 1975 and finished it in May 1988 upon going through hardships. Awarded The Third Mao Dun Literature Prize, this novel provides a panoramic view of the social life in China's urban and rural areas and the great changes in the Chinese people's thoughts and emotions in the era of reform. Leo Tolstoy was a critical realist writer and thinker in Russia in the nineteenth century. He successively overhauled his novel Anna Karenina 12 times and produced up to 20 versions of the beginning part of Resurrection, another of his novels.

The development of culture is interrelated with the future of the country, and the inheritance of culture is connected with the development of the country. Xi Jinping believed that to achieve the great renewal of the Chinese nation is a great cause that surpasses the ancients and amazes contemporaries, which calls for a great spirit of perseverance and great works to boost popular morale. He places great expectations on literary and artistic work, and he has repeatedly identified the problems that exist in these fields. For example, we have many fine works but few top masterpieces, some works are alienated from people and life, and some are insignificant, designed merely to entertain readers or to provide audiences with history. Xi Jinping cited the ancient, contemporary, and foreign writers' celebrated dictums and stories about a dedicated attitude, creation without hurry and haste and hard work just to urge the writers and artists to bear the responsibility of presenting fine works that enjoy a widespread high reputation and enduring fame, and not to pursue quick success with shoddy works. At the Symposium on Literature and Art held in 2014, he also related that in Gustave Flaubert's novel Madame Bovary, there was a page that took him 5 days to produce, and when Cao Xueqin was producing A Dream of Red Mansions, he reviewed it ten times and made additions and deletions five times. With these stories, he sent word to the writers and artists that fine literary and artistic works can hardly be produced without the spirit of diligently striving for excellence.

\section{"Serve the Country with Utmost Loyalty"}

Speaking of reading literature, I perused literary works mostly in my teens, and I shifted my focus to political books afterward. When I was very young, about 5 or 6 years old, at which time my mother worked in the Central Party School, once she took me to buy books from the Xinhua Bookstore on the way from the Party School to Xiyuan. That day I was unwilling to 
walk because of laziness, so she carried me on her back. We wanted to buy picture-story books about Yue Fei, and there were two versions of books about him. One was a book series, The Legend of Yue Fei, with one book contained in it entitled "Yue Fei's Tattoos", and the other version was about the story, "serve the country with utmost loyalty." Mother bought both versions for me. Returning home, she told me the story that Yue Fei's mother tattooed the characters “精忠报国” on his back, which meant serve the country with utmost loyalty. I said, "Having characters tattooed on his back! That must have been painful!" My mother replied, "Painful, of course. But the idea was forever etched in his mind." From then on, I have kept the words "serve the country with supreme loyalty" firmly in mind as my lifelong goal.

- General Secretary Xi Jinping's Affinity for Literature (People's Daily, October 14, 2016, Page 24).

\section{Commentary}

The passionate love for our nation is a cultural heritage running through Chinese history of several thousand years, which is deeply rooted in the heart of every excellent Chinese citizen. The story "Yue Fei's mother tattooed characters on his back" illustrates the advocacy of family tradition and education in China as well as the Chinese people's passionate love for our motherland.

Yue Fei, whose courtesy name was Pengju, was born in 1103 in Tangyin County, Xiangzhou (present-day Tangyin County, Henan Province). He was a famous general in the resistance against Jin's invasion in the Southern Song Dynasty, among the "Four Great Generals of Zhongxing Period", and he was also a famous militarist and strategist in Chinese history. He joined the army during the last Northern Song Dynasty. From 1128 to 1141, he led his invincible troops to fight several hundred battles of all scales with Jin armies, and he eventually "reached the position of general." In 1140, Yue Fei commanded his troops to fight northward to strike back at Wanyan Wuzhu from the Jin Dynasty, who broke the treaty of alliance with Song by attacking Song. Yue Fei reconquered Zhengzhou, Luoyang, and other places successively and marched troops into the town of Zhuxian after defeating Jin armies in Yancheng and Yingchang. Defeated in the town of Zhuxian, Wuzhu lamented, "To shake Yue's army is much more difficult 
than to shake a mountain." However, although they had the advantage over the enemy, Emperor Gaozong of Song and Qin Hui, then Chancellor of Song, sued for peace, and even sent 12 "gold-character plates" to force Yue Fei's army to retreat. Forced by the isolated and helpless situation, Yue Fei withdrew the troops. At the time when Song and Jin were conducting peace negotiations, Yue Fei was jailed due to the frame-up by Qin Hui, Zhang Jun, and their wing. In January 1142, Yue Fei was executed on a groundless charge of rebellion, and his eldest son Yue Yun and Zhang Xianyi, a military officer under his command, were killed together with him. During the reign of Emperor Xiao of Song, Yue Fei was vindicated and was reinterred in Xixialing near West Lake.

When Yue Fei marched northward to fight against the Jin armies, he wrote the poetic masterpiece The River All Red: "Wrath sets on end my hair, I lean on railings where I see the drizzling rain has ceased. Raising my eyes towards the skies, I have long sighs, my wrath not yet appeased. To dust is gone the fame achieved at thirty years; like the cloud-veiled moon the thousand-mile land disappears. Should youthful heads in vain turn grey, we would regret for aye. Lost our capitals, what a burning shame! How can we generals quench our vengeful flame! Driving our chariots of war, we'd go to break through our relentless foe. Valiantly we'd cut off each head; laughing, we'd drink the blood they shed. When we've reconquered our lost land, in triumph would return our army grand." (Translated by $\mathrm{Xu}$ Yuanchong) This $\mathrm{Ci}$ was imbued with a spirit that seemed to conquer mountains and rivers, which fully manifested Yue Fei's patriotic emotion and lofty aspirations to serve his country and recover his homeland.

Yue Fei's virtues of loyalty, patriotism, and integrity were inherited from the instruction by his parents and teachers. The historical story of "Yue Fei's Tattoos" was first read in the hand-copied book of the Qing Dynasty, Views on Legends, as well as General Yue Fei by Qian Cai. According to the History of Song-Biography of Yue Fei, when Yue Fei suffered an undeserved grievance, he ripped his jacket to reveal the four tattooed characters of "serve the country with the utmost loyalty" on his back. This proved that he was clearly innocent of the charges. This story has had a profound influence on later generations and has been passed down to the present.

$\mathrm{Xi}$ Jinping once compared the formation of values to "buttoning up our coat", saying that "Young people should 'button right' in the early days of their life." Yue Fei's story "serve the country with utmost loyalty" was the "very first button" in Xi Jinping's teens. At the Symposium on Literature and Art, Xi Jinping recalled the influence of The Legend of Yue Fei on him 
while discussing his affinity for literature. The affection for the motherland reflected by the story always inspires him to cherish the people and never stop fighting. Communists' passionate love for our motherland is clearly illustrated by how we cherish the people and deliberate on how our country can prosper and continue to renew its aspirations'.

\section{Borrowing A Book from 30 Miles Away}

During my state visit to Russia last March, I mentioned at the symposium with Russian sinologists that I had read the works of many Russian writers such as, What Is to Be Done? by Chernyshevskiy. I was young that I read this book, and it gave me a great shock. When I paid a state visit to France this March, I discussed the influence of French literature and art on me. Many of our Party's older generation leaders had studied in France. Influenced by them, in my youth I had a strong interest in French literature and art. In Germany, I discussed my experience of reading Faust. When I was living and working in the countryside of Shaanxi Province as an educated youth, I heard that another educated youth had the book Faust. So I walked 30 miles to borrow the book from him. Later, he also walked 30 miles to get the book back. Why did I talk about these reminiscences with the foreigners? I did so because literature and art are world languages. They are all about society and life. It is thus easiest to achieve mutual understanding and spiritual communication in this way.

- Speech at the Symposium on Literature and Art (October 15, 2014).

\section{Commentary}

No era will be without its heroes, and everyone has a place for his role model in his heart. Rakhmetov, the leading character in the novel What Is to Be Done?, was exactly such a hero who was etched on the Russian' soul, and he also served as a role model who influenced a generation of Chinese.

Nikolay Chernyshevsky was a Russian revolutionist, philosopher, writer, and critic. Vladimir Lenin praised him as "the young helmsman in the storm of the future", and Vladimir Plekhanov compared him to "Russia's Prometheus". He was arrested by the Czarist government in 1862 for propagating progressive thoughts and criticizing the reality of Czarist Russia. In 1864, he was sentenced to 7 years of hard labor and exiled to Siberia for 
life. In captivity and exile, he produced many excellent works imbued with a passion for revolution, including What Is to Be Done? and Prologue. What Is to Be Done? revolves around three themes: freedom of labor, women's liberation, and secret revolutionary activities. It suggests that the people can only rid themselves of adversity through struggle. The leading character, Rakhmetov, had been a woodcutter, sawyer, stonemason, and boat tracker. To strengthen his revolutionary will and devote himself totally to his ideal, he chose to live a life of extreme frugality.

$\mathrm{Xi}$ Jinping recalled that his generation was deeply influenced by the Russian classics. What Is to Be Done? was one of them, which caused a great shock in his mind. According to Xi Jinping, "The leading character Rakhmetov lived an ascetic life. To temper his will, he even slept on a blanket full of nails, causing himself to bleed all over. At that time, we believed we needed to train to attain willpower like this, so we all slept on a heatable brick bed without a mattress. When it rained, we were exposed to the rain; when it snowed, we rubbed the snow on our bodies and took a cold bath by a well. This was all due to the influence of this book."

Faust is also a work of profound influence. It has been said that "One cannot write a history of world literature without discussing Johann Wolfgang von Goethe; similarly, it is difficult to understand Goethe without reading Faust." Faust is a poetic drama written by Goethe on the basis of a German folktale. The devil entices Faust to sign a pact with him: the devil will do everything that Faust wants during his lifetime, and in exchange Faust must devote his soul to the devil after death. With this pact as the background, Goethe interpreted many significant issues concerning worldly ideals and the future of humanity, and he declared the victory of the enterprising spirit of human beings. Xi Jinping has mentioned on multiple occasions his anecdote of reading Faust by borrowing the book from 30 miles away, which vividly demonstrates the power of literature.

Describing his affinity for literature and recalling the influence of reading at the different stages of his life, Xi Jinping conveyed an air of erudition and an amiable charisma. These qualities were cultivated by extensive reading. His story demonstrates the value of a good literary work: a good literary work should take root in people's lives and be able to enlighten us as to all aspects of human experience, including career and life, prosperity and adversity, dreams and expectations, love and hate, and existence and death.

Literature and art are the language of the world. Literature is a bridge of communication. As Xi Jinping shares his experiences of reading, he also communicates the value of shared knowledge and the possibility of cultural 
exchange. We should be inclusive of other civilizations, and we should take time to study them. Literary works are the best way by which the countries and nations of the world can engage in mutual understanding and exchange. As Xi said, "When we talk about literature and art, we are talking about society and life. It is the easiest means for us to understand and communicate with each other."

\section{Why Did China's Science and Technology Lag BEHIND}

I have been wondering about why our science and technology gradually lagged behind in the late Ming (1368-1644) and early Qing (1644-1911) dynasties. Studies show that Qing Emperor Kangxi was very interested in Western science and technology. He invited Western missionaries to give him lectures on astronomy, mathematics, geography, zoology, anatomy, music, and even philosophy. More than 100 books on astronomy were introduced to him. When did he study these subjects, and for how long? He continuously studied them for 2 years and 5 months sometime between 1670 and 1682. He began his study quite early and learned quite a lot. The problem was that, at that time, although some people were interested in Western learning and had learned quite a lot of it, they did not apply what they had learned to social and economic development. Rather, they simply discussed the knowledge. In 1708, the Qing government asked some foreign missionaries to draw a map of China. It took them 10 years to complete The Map of Imperial China-the first of its kind at that time. However, this important work was confined to the imperial storehouse as a top-secret document, away from the public eye. Therefore, it had no impact on social or economic development. However, the Western missionaries who had drawn the map took the data back to the West and had it published. Hence, for quite a long time, the West knew China's geography better than the Chinese people did. What can we learn from this story? It means that science and technology must be combined with social development. No matter how much one has learned, it cannot possibly have any impact on society if the knowledge is merely set aside as a novelty, refined interest, clever trick, or doubtful craft. 
- Transition to Innovation-driven Growth (June 9, 2014), from the Xi Jinping: The Governance of China, Edition 2014, published by Foreign Language Press.

\section{Commentary}

Qu Yuan, a Chinese patriotic poet from southern Chu during the Warring States Period, had a work entitled Tian Wen. The literal meaning of the title is "questions to heaven," and this work consists of over 170 questions on astronomy, geography, nature, and life, which was praised as "an eternal extraordinary masterpiece." In regard to "questions to heaven", there are some about Chinese history. One of them is the "Needham Question": why did modern civilization in science, technology, and industry not originate from China, the most advanced country in science, technology, and economy at that time?

It is undeniable that an important factor allowing for China's suffering from foreign aggressions as a poor and weak country in modern times was that China has repeatedly missed the scientific and technological revolutions, and it has not applied its advanced knowledge to economic and social development. Although "The Golden Age of Three Emperors-Kangxi, Yongzheng and Qianlong" has been praised by people through the ages, by taking a comprehensive look at the history of the world, it becomes clear that the so-called "golden age" was, to a large extent, merely an "illusion." When China was under the Kangxi administration, Europe ushered in an era of the highest achievement in the history of science, during which time Francis Bacon, Newton, Descartes, and other great philosophers and scientists emerged. Emperor Kangxi was also very studious. He got along with foreign missionaries including students and teachers, often spending 3-4 hours a day with them to become acquainted with many types of precision instruments and delving into various subjects with them. He liked mathematics, and especially liked exploring the use of all types of mathematical measuring tools, such as semicircle instruments, dividers, and geometric polyhedron models. According to the French missionary Joachim Bouvet, for 2 years, Kangxi spent all his spare time on mathematics. Although he was praised by the missionary as "the greatest emperor" and "the wisest emperor", he only considered the development of science to be his hobby instead of thinking about the methodology and worldview lurking within science and spreading scientific knowledge from the West across China. 
As the ruler refused to "shake hands" with Western industrial civilization and share advanced technologies and knowledge across China, our nation walked into the bitterly painful era as a semicolonial and semifeudal country.

During Xi Jinping's state visit to Europe in March 2014, the Chancellor of Germany, Angela Merkel, presented him with the first accurate map of China drawn by Germany in 1735. Few people know that Emperor Kangxi had organized missionaries to complete an unprecedentedly advanced map of China-The Map of Imperial China-as early as more than a decade before the German map. After The Map of Imperial China was completed, Jean Baptiste Regis, a member of the Society of Jesus who had participated in the drawing of the map, sent it to his home country of France. Subsequently, The New Map of China was produced based on The Map of Imperial China and was published publicly in Europe. In 1840, when the British sent military ships to China based on The New Map of China and bombarded the gate of the Qing Empire, The Map of Imperial China was still shelved in the Forbidden City, without playing a practical role in promoting economic and social development.

Not only does Xi Jinping read history books and have knowledge of Chinese history but he also enjoys thinking about and studying questions of governance-not simply for the sake of discussing science and technology but to apply them to social and economic development. This is the essence of innovation that he obtained from the story of the relationship between Kangxi and science, and it has also served as his solution to China's "Achilles' Heel." If we simply discuss science, we cannot promote our nation's development. It is said that "Science and technology must be combined with social development." Only if we free ourselves from the "ivory tower" and avoid isolation in innovation can scientific and technological innovation produce greater motivation for and create more miracles of development, just like "a fulcrum that is said to be able to level the earth."

In Xi Jinping's speech at the 17th General Assembly of the Members of the Chinese Academy of Sciences and the 12th General Assembly of the Members of the Chinese Academy of Engineering, he noted that our scientific and technological achievements could not be smoothly converted into productivity because there are institutional bottlenecks in the scientific and technological innovation chain and loose connections among the various links in the innovation and conversion process. Xi Jinping said that if we decide that scientific and technological innovation is a new engine to drive our development, then reform is the ignition system that is essential to start 
the engine, thus we should take more effective measures to improve the ignition system and let the new engine run at full speed.

\section{Where Did the Time Go?}

Speaking of hobbies, I like reading, watching movies, traveling, and strolling. As can be seen in this post, I have almost no private time. In China, there is a song titled "Where Did the Time Go?," which became popular during the Chinese Spring Festival this year. For me, the question is where my private time goes. Of course, I spend almost all of it on my work. The only thing I have managed to keep as a hobby is reading, which has become my way of life. It invigorates my mind, gives me inspiration, and cultivates my moral force. I have read many works by Russian writers such as Ivan Krylov, Alexander Pushkin, Nikolai Gogol, Mikhail Lermontov, Ivan Turgenev, Fyodor Dostoevsky, Nikolay Nekrasov, Nikolay Chernyshevsky, Leo Tolstoy, Anton Chekhov, and Mikhail Sholokhov. Many wonderful chapters and stories in those books have remained in my memory.

In terms of sports, I like swimming and mountaineering. I learned to swim as early as 4 or 5 years old. I also like football, volleyball, basketball, tennis, and martial arts. Among the ice and snow sports, I love watching ice hockey games, speed skating, figure skating, and freestyle skiing. Ice hockey is my favorite. It not only calls for personal strength and skill but also teamwork and collaboration, which makes it a great sport.

- Xi Jinping Gave an Exclusive Interview with Russian Television (February 7, 2014) (People's Daily, February 9, 2014, Page 1).

\section{Commentary}

"Where did the time go? I had not yet enjoyed youth before I got old. Raising and cultivating my children for a lifetime, my mind is full of their cries and laughter..." The Spring Festival Gala of CCTV 2014 made the song Where Did the Time Go popular. The song extolls parental love. In February 2014, $\mathrm{Xi}$ mentioned the song in an exclusive interview with Russian TV, triggering a nationwide discussion on "Where Did the Time Go". 
So where does Xi Jinping's time go? Just as he said, he spends all of it on his work. According to incomplete statistics on the basis of the public reports issued in 2015, in that year alone, $\mathrm{Xi}$ Jinping attended at least 61 important meetings, including 14 meetings of the Political Bureau of the CPC Central Committee, 11 meetings of the central leading group for deepening overall reform, ten working meetings, three meetings of the standing committee of the Political Bureau, and 23 other important meetings and conferences. During that year, he took part in the nine regular study sessions held by the Political Bureau and made eight trips for state visits.

Xi Jinping spent most of his spare time reading. Sergei Brilyov, Russian television host who conducted an exclusive interview with Xi in Sochi, said he "particularly liked" Xi's eyes because "he saw the light of thought from them." The "light of thought" can be partly attributed to reading. $\mathrm{Xi}$ regards reading as a lifestyle: "Whenever I was free, I would pick up and read a book, and every time I found it to be beneficial"; "A book is like a treasure. Once you explore the secrets hidden within it, you will benefit from it throughout your lifetime."

$\mathrm{Xi}$ Jinping visited Russia and three African countries for the first time a week after assuming the presidency. In consideration of his overly tight schedule, the Chinese Embassy in Russia intended to shorten the length of some of his activities to provide some rest time for Xi, "but President $\mathrm{Xi}$ persisted in keeping the original schedule." "Although I feel weary, I enjoy it," said Xi. This is Xi Jinping, a president who races against the clock as he works diligently for the country and the people and strives after the Chinese Dream of rejuvenating of the nation.

$\mathrm{Xi}$ Jinping's story about time is an inspiration to all Party members and officials. We should make full use of our spare time to study for the enrichment of our minds while sparing no effort to perform our duties. Our nation always stresses that one should pursue self-cultivation by reading books, and one should cultivate morality as one enters politics. As our traditional culture advocates, study and morality cultivation are not only the foundations for one to gain a foothold in society but also the key to handling government affairs. Xi Jinping once profoundly asserted that "Leading officials' power of personality is more and more critical for leadership, and a predominant way to generate the power of personality is to study by reading books." 


\section{Heroes Emerge from a Nation's Youth}

A quick look at world history suggests that many thinkers, scientists, and writers produced their important creations in their youth, the full-flowering of their life, during which time they were quickest witted in their lifetime. When The Communist Manifesto was published, Karl Marx was 30 and Friedrich Engels was 28. Isaac Newton and Gottfried Wilhelm Leibniz discovered calculus at the ages of 22 and 28, respectively. Charles Darwin embarked on his voyage around the world at the age of 22 and famously produced The Origin of Species thereafter. Thomas Edison invented the phonograph when he was 30 and the electric light when he was 32. Marie Curie discovered that radium, thorium, and polonium were radioactive when she was 31 and later won the Nobel Prize for their discovery. Albert Einstein proposed the special theory of relativity when he was 26 and general relativity at 37. Li Zhengdao and Yang Zhenning proposed the parity nonconservation of weak interaction when they were 30 and 34, respectively. Jia Yi, the political commentator of the Western Han Dynasty, was only 32 when he died. Wang Bo, the author of the masterpiece A Tribute to King Teng's Tower, also died young at age 27.

- Speech at the Collective Talks with Members of the New Leadership of the Central Committee of the CCLY (June 20, 2013).

\section{Commentary}

"If we have chosen a position in life in which we can above all work for mankind, no burdens can hold us back because they are sacrifices for the benefit of all; then we shall experience no petty, limited, selfish joy, but our happiness will belong to millions, our deeds will live on quietly but perpetually at work, and over our ashes will be shed the hot tears of noble people."

This is an excerpt from Reflections of a Young Man on The Choice of a Profession, an essay by Karl Marx when he was 17 years old. At the time, Marx was graduating from high school and had come to a fork in his path. He had to make up his mind whether to go to college or get a job. Some of his classmates wished to be poets, scientists, or philosophers, some intended to be clergies or priests, and some hoped to live a luxurious life as capitalists. Unlike those who were motivated by self-interest and pursued 
individual happiness, Marx considered a career choice on the basis of his understanding of society and his philosophy toward life. Hence, came this masterpiece.

Isaac Newton, Charles Darwin, Albert Einstein, and Marie Curie all made great discoveries and inventions at a young age. The youthful days are the best time for one to engage oneself in creation because, during this period, one is quick-witted and full of energy, able to accumulate knowledge and experience in a fast and efficient way, and one dares to follow one's heart and make a difference with courage and determination. At the same time, the youthful days are also a peak time for the generation of new discoveries, creations, and knowledge. This is almost a universal law.

There have been many young and promising talents in Chinese history. For example, Jia Yi became well known for his literary skills in his youth. His precociousness caught the attention of Emperor Wen of Han. The emperor made him a "professor" when he was only 21 years old, and he thus became the youngest professor in the imperial court at the time. When Jia later served as Grand Tutor to Liu Yi, Prince of Liang, he wrote the Countermeasure Against Public Security Issues, which contains the memorials he submitted to the emperor on government affairs including the invasion of Xiongnu on the border of Han, unsound regulations, and the separatist regimes established by the dukes and princes. The Countermeasure Against Public Security Issues was praised by Mao Zedong as the greatest political essay of the Western Han. Another example is from Wang Bo, a scholar of the Tang Dynasty who had been smart and studious since his childhood. According to the Old Book of Tang, he began writing beautiful literary pieces at the age of six and was reputed as a child prodigy. Although he drowned at the young age of 27, he left many great lines for posterity, for example, "If you have a friend from afar who knows your heart, distance cannot keep you two apart"; and "A solitary wild duck flies alongside the multi-colored sunset clouds, and the autumn river shares a scenic hue with the vast sky." He was grouped with Luo Binwang, Lu Zhaolin, and Yang Jiong as the "Four Paragons of the Early Tang."

$\mathrm{Xi}$ Jinping pays great attention to the development of young people. At the collective talks with members of the new leadership of the central committee of the Chinese Communist Youth League (CCYL), he entrusted them to take the lead in studying hard, working hard, enhancing selfdiscipline, and maintaining close ties with the youth. As a fine example is 
probably the most convincing argument, he has told stories about luminaries such as Marx, Newton, and Wang Bo who achieved great accomplishments in their youth to encourage the new leadership of the CCYL central committee and even the Chinese youth to resolutely strive for success in extraordinary causes.

$\mathrm{Xi}$ Jinping likes to go among the young people, and he often exhorts them to maintain their spirit of struggle and dedication. He successively wrote to the Youth League Branch of the Grade 2009 undergraduate classes of the School of Archaeology and Museology, Peking University, Benyu Volunteer Team from Huazhong Agricultural University, and the representatives of the Baoding University graduates engaged in teaching assistance in West China to inspire them to combine their personal ideals into national and ethnic causes and strive to use their talents for our nation. At a symposium with the teachers and students of Peking University, he also offered the metaphor of "button up our coat" to exhort them to attach importance to value formation, saying "The life buttons are required to get off to a good start." Our younger generation has a promising future, and it will accomplish much. In Xi's view, "It is a law of history that 'the waves of the Yangtze River from behind drive on those ahead', and it is the responsibility of young people to surpass their elders."

\section{The Revolutionary Youth}

In the history of our Party, many outstanding leaders have established the revolutionary ideal in their youth: to fight for the people. Comrade Mao Zedong determined to devote himself to the prosperity of the Chinese nation early in his youth. He founded Xinmin Institute with He Shuheng and Cai Hesen at the age of 25 and attended the First Conference of the $\mathrm{CPC}$ at 28. When he was 34, he headed the Autumn Harvest Uprising and led the insurrectionary army to establish the first rural revolution base of China on the Jingang Mountains. Comrade Zhou Enlai headed the Tianjin Patriotic Student Movement when he was just 21 and participated in the founding of the Chinese Communist Youth League in Europe when he studied in France on a work-study basis at the age of 24 . He also led the Nanchang Revolt and the building of the army of the CPC at 29, and he was elected to the standing committee of the Political Bureau of the Sixth CPC Central Committee the next year. Comrade Deng Xiaoping went to study in France under a work-study program at 16 and joined the Chinese Communist Youth League in Europe 2 years later. He took the post of 
the Secretary General of the CPC Central Committee when he was 23 and headed the Baise Uprising and built the Seventh Army of the Chinese Workers' and Peasants' Red Army when he was 25.

- Speech at the Collective Talks with Members of the New Leadership of the Central Committee of the CCLY (June 20, 2013).

\section{Commentary}

Youth is fleeting and cannot be remade; thus, how can we make the most of our lot and have a wonderful life? This is "a question of youth" that has been asked by young people throughout the ages. In hope of rescuing our nation from peril, Mao Zedong, Zhou Enlai, and Deng Xiaoping all resolutely devoted themselves to the revolutionary cause, imprinting the mark of youth on the history of our Party. This mark represents their ardent faith in the Party as well as the courage to rescue our nation.

"I, your son, am determined to go out of my hometown, and I will not return until I succeed in a certain field of study. If I die in a place far from home, it will not be necessary to bury me in my hometown because every place I set foot is a good place to lay my bones." At the age of 17, Mao Zedong left his hometown for Xiangxiang County, Hunan Province to study there. Before his departure, he wrote this poem on a slip of paper and stuck it in his father's account book to communicate his ambition and determination. From then on, the sufferings of the people and the hardships of the nation became the chief concern of young Mao Zedong. In his $20 \mathrm{~s}$, he successively founded Xinmin Institute and the Students' Union of Hunan, started the publication of the Xiangjiang Review and participated in the founding of the early organization of the Changsha Communist Party. He attended the First Conference of the CPC at 28. The young Mao Zedong was just like what he wrote in Changsha-To the Tune of Qin Yuan Chun, "When, students in the flower of our age/Our spirit bright was at its height/Full of the scholar's notable rage/We criticized with all our might/Pointing to stream and hilWriting in blame or praise/We treated like dirt all mighty lords of old days."

In Europe in the 1920s, when the CPC had just been founded, there was a political force made up of young Chinese called the "Chinese Communist Youth League in Europe." In 1915, Cai Yuanpei and Wu Yuzhang headed the founding of the Diligent Work-Frugal Study Movement and called 
on Chinese students to study in France on a work-study basis. Some of those students later became Marxists in France including Zhou Enlai, Zhao Shiyan, Cai Hesen, Li Weihan, Wang Ruofei, Li Lisan, Xiang Jingyu, Chen Yi, Chen Yannian, Chen Qiaonian, Nie Rongzhen, Deng Xiaoping, and Li Fuchun. They established the Paris Communist Party in 1921 and founded the Chinese Communist Youth League in Europe the following year. At that time, 24-year-old Zhou Enlai was in charge of propaganda in the executive committee of the party and 18-year-old Deng Xiaoping joined the organization as a newcomer. Our Years in France is a television series that presented their experiences in France, which was very popular among Chinese audiences for a while.

After returning to China, Zhou Enlai served as the Director of the Political Department of the Whampoa Military Academy and headed the establishment of the CPC-controlled Ye Ting's Independent Regiment, a revolutionary armed force established for the Northern Expedition. When he was 29, he led the Nanchang Revolt, the Party's first military action against the Kuomintang reactionaries, greatly contributed to the building of the people's army. Deng Xiaoping, who returned to China after studying in the Soviet Union, became involved in the revolutionary movement in China. $\mathrm{He}$ assumed the post of Secretary-General of the CPC central committee at the age of 23, led the Baise Uprising and built the seventh battalion of the Chinese Workers' and Peasants' Red Army at 25.

Telling the stories of the revolutionary youth of Mao Zedong and other revolutionary predecessors, Xi Jinping has inspired contemporary youth to adhere to their ideals and to struggle unremittingly for our nation's prosperity and our people's happiness. Recollecting the older generation of communists' soul-stirring struggle in their youth and encapsulating China's past century, which was full of ups and downs before the young people, he aimed at enlightening them to their mission and responsibilities, indestructible faith, and the determination of and confidence in struggle. China's strength is embodied in the strength of the youth, and China's dream is to be realized through the struggle of the youth. As Xi noted, the youth are fresh troops on the front lines to build a moderately prosperous society in all respects. They are a generation with many calls for their kind effort, from obtaining a decisive victory in building a moderately prosperous society in all respects to finding a solution to the issues and contradictions emerging from the process of reform and development. As long as the thousands upon thousands of young people release their youthful dreams and keep their morale high, China will certainly radiate new glory. 


\section{KeEPING UP WITH The Times}

In modern times, previously held knowledge is becoming outmoded at an ever-increasing pace by a whole range of new knowledge, new things, and new states of affairs arising all over. Academics have noted that before the eighteenth century, the body of human knowledge doubled within a period of approximately 90 years. Since the 1990s, there has been an exponential acceleration in this process- the body of human knowledge is now estimated to double every $3-5$ years. Thus, over the past 50 years, human beings have produced knowledge of an amount exceeding the aggregate generated over the previous 3000 years. It is also believed that in the age of agro-farming, a few years of study sufficed for one's lifetime; in the age of industrial economy, one had to study for at least a decade to obtain all the knowledge necessary for one's life; and in this age of the knowledge economy, one can only keep up with the times through lifelong study. If we fail to improve our knowledge in a wide variety of areas, if we do not take the initiative to learn about science and culture, if we are unwilling to conscientiously update our knowledge and improve our knowledge structure, develop the broadest possible perspective and broaden our horizons, our professional competence will become stagnant. As a consequence, we will not be able to grasp the initiative and prevail. Ultimately, the future will pass us by.

- Speech at the Celebration Assembly of the 80th Anniversary of the Central Party School and the Opening Ceremony of Its 2013 Spring Semester (March 1, 2013).

\section{Commentary}

"In the vibrant woods, the young leaves hurry the defoliation of the current ones; in a rushing river, the waves ahead make way for those behind." The supersession of the old by the new is a general law of the universe. In the process of knowledge production, the supersession speeds up dramatically. Research by UNESCO shows that before the eighteenth century, human knowledge was updated every 80-90 years; from the nineteenth to the early twentieth century, the validity term of knowledge was shortened to 30 years; from the 1960s to the 1970s, the validity term for common subjects was $5-10$ years, and by the end of the twentieth century, knowledge 
was being updated every 5 years in most subjects. As we enter into the twenty-first century, our knowledge is updated every $2-3$ years.

A scholar once put forward the term, "the half-life of facts," derived from the principle of radioactive decay with regard to the development and change of knowledge. If one who has a lot of knowledge or is specialized in a certain field no longer studies, he will experience truth decay due to the half-life of facts. This means that the basic knowledge he grasps is still useful; however, half of his knowledge has already become outdated and replaced by new knowledge. Today, knowledge is undergoing "fission" at a tremendous pace. It is estimated that knowledge maintained a half-life of 50 years before 1950; however, in the twenty-first century, this duration has been shortened to approximately 3.2 years. For a senior IT engineer, half of his knowledge will become obsolete in 1.8 years. By the same token, if one never studies or stops studying for a long time, it is difficult for him or her to keep pace with society. It is often the predicament that many people "have no alternative when the tried and trusted methods fail, or they dare not to adopt stricter measures when soft ones prove inadequate." This is precisely because they do not equip themselves with the latest knowledge and skills that could help them escape the trap of "the half-life of facts."

It is our Party's tradition to attach importance to study. As early as the Yan'an Period, Mao Zedong had identified the issue of a "competence crisis". He drew an analogy between studying and "running a shop"when your goods are sold out, you have to replenish your stock to keep the shop running. According to this analogy, "to replenish" is to learn.

"To a large extent, we Chinese Communists have relied on learning for our achievements, and we will surely continue to do so in the future." At the Celebration Assembly of the 80th Anniversary of the Central Party School, Xi Jinping stressed the importance of study in this way. It was said in The Garden of Stories that, "If you want to enhance your ability, you must study; if you want to make the blade sharp, you must sharpen it." This is a saying cited by Xi Jinping in Fresh Ideas of Zhejiang to exhort the leading officials to study more and to place study and reading high on their list of priorities. In the foreword to the training material for the fourth group of national officials, Xi Jinping highlighted that "We should study hard to improve our knowledge in a wide variety of areas and strive to enhance our abilities in practice. We should update our knowledge at a faster pace, optimize our knowledge structure, develop the broadest possible perspective and broaden our horizons. We must study to avoid the 
bewilderment that results from inadequate knowledge, the blindness that results from insensibility, and the chaos that results from ignorance. We must also study to overcome professional deficiencies, the dread of incompetence and outdated capabilities."

$\mathrm{Xi}$ also once proposed a "storage battery theory": now it is no longer the era that one needs charge oneself only once throughout one's lifetime; if one wants to be energized continuously, one must charge oneself unremittingly like an efficient storage battery. Unlike dull sermons, such a vivid summation is not only easy to understand and practice but it also inspires the audience, who interprets study as a lifestyle and necessity for progress, not a mandatory task.

\section{LEARNING BY THINKING}

Our ancestors left many stories on diligent study to us. To study, they tied their hair on a house beam or jabbed their thigh with an awl to keep themselves awake, or they made use of the neighbor's light by boring a hole in the wall or read by the light of bagged fireflies or the reflected light of snow. These stories have been passed from person to person with approbation, and such a spirit of diligence is worth bearing in mind. We should all calm down and delve deeply into books without distractions and engage in thorough discussion. "If one learns from others but does not think, one will be bewildered. If, on the other hand, one thinks but does not learn from others, one will be imperiled." This saying of Confucius makes a very good point. Learning and thinking are interrelated and mutually reinforcing. We must not separate them from each other. In the process of learning, we should connect the problems that we have encountered in actual work and think them over repeatedly. This is helpful in cultivating and improving our theoretical thinking and strategic thinking abilities. The Central Party School holds trainee forums and political experience exchange activities every semester, which supports further study and discussion of the governing experience. Participants also engage in exchange and sharing of their learning experiences during class breaks or free time for mutual enlightenment.

- On the Study of the Trainees of the Central Party School-Speech at the Opening Ceremony of the Central Party School in 2012 Autumn Semester (September 1, 2012). 


\section{Commentary}

In An Exhortation to Learning, Hsun Tzu said that "Truly, if you do not climb a high mountain, you will be unaware of the height of the sky. If you do not look down into a deep gorge, you will be unaware of the thickness of the earth." Learning is a powerful approach to changing one's destiny and to seeing the world around us. Studying diligently has been regarded as an excellent quality since ancient times.

According to the Stratagems of the Warring States, Su Qin studied diligently and strived for progress from his youth. It is said that "Every time he felt too tired and sleepy, he jabbed his thigh with an awl. As a result, blood flowed to his feet." The Book of Han also tells a story of diligent study: "Sun Jing, whose style name was Wenbao, was diligent and studious. He studied from morning until night. To keep himself from dozing off, he tied his hair to the house beam." These two stories are combined into a Chinese idiom that means "to tie one's hair on the house beam or stab one's thigh with an awl to keep oneself awake."

In the Western Han Dynasty, the writer Kuang Heng made use of his neighbor's light to study by boring a hole in the wall. According to $A$ Miscellany of the Western Capital, Kuang Heng was born in a poor family and had no money to buy a candle for reading at night, so he bored a hole in the wall to make use of his neighbor's light. Similarly, in the Jin Dynasty, Che Yin read by the light of bagged fireflies, while Sun Kang by the reflected light of snow. Deprived though they were, they studied around the clock, unwilling to waste a single second. There have been many other similar stories. Confucius read The Book of Changes over and over so that the leather cords holding the pages broke many times. In the Eastern Jin Dynasty, young $\mathrm{Zu}$ Ti rose upon hearing the crow of a rooster every day to practice swordsmanship. In the Northern Song Dynasty, Yang Shi and his friend You $\mathrm{Cu}$ once sought the advice of a scholar named Cheng Yi. When they arrived at Cheng's house, it snowed very heavily, and they were informed that Cheng was sleeping. In order not to disturb the instructor, they waited outdoors in the snow until Cheng woke up.

In study, we should also pay attention to method and manner. In this regard, The Analects provides advice of considerable referential value. The book states that "If one learns from others but does not think, one will be bewildered. If, on the other hand, one thinks but does not learn from others, one will be imperiled." This means if one learns without thinking, 
he will acquire nothing because of bewilderment. If one thinks without learning, he will be imperiled because of bewilderment. The Analects also proposed that one should "Learn widely and be steadfast in one's purpose, inquire earnestly and reflect on what is at hand, and there will be no need to look for benevolence elsewhere." By doing so, we will ultimately become benevolent.

Introducing the ancients' deeds of studying diligently and their ways of studying, Xi Jinping encouraged the trainees of the Central Party School to study hard and continue to think. As early as when he worked in Zhejiang Province, he proposed the idea to "take an initiative to start a 'revolution of study'." He thinks highly of the role of "thinking" in study: "Thinking is a further step to deepen one's reading. It is an inevitable step to gain access to cognition, and it is the key to capturing the essence of a book." Albert Einstein said, "Studying requires continual thinking and rethinking, which is a learning method that has helped me become a scientist."

\section{To Have a Good Grasp of Original Works}

In the preface to Capital, Volume III, Friedrich Engels noted "When a man wants to address scientific questions, he should above all learn to read the works he wishes to use just as the author had written them, and above all without reading anything into them that they do not contain." For the majority of Party members and officials, it is inevitable that they will encounter some difficulties at the initial stage of reading some original works. However, Marxism is the scientific truth that guides the working class to understand the world and to transform the world. As long as we make great efforts to read these works, we will definitely come to have a good grasp of it. "The method of analysis that I have employed, and which had not previously been applied to economic subjects, makes the reading of the first chapters rather arduous," said Karl Marx after the publishing of Capital, Volume I. "This is a disadvantage I am powerless to overcome except by forewarning and forearming those readers who zealously seek the truth. There is no royal road to science, and only those who do not dread the fatiguing climb of its steep paths have a chance of gaining its luminous summits." Lenin said that the task of helping college students to fully comprehend the question of the state is "a most complex and difficult one." He once recommended that students should "devote some time to reading at least a few of the most important works of Marx and Engels." He said, "Some of you may at first be dismayed by the difficulty of the 
exposition, I must again warn you that you should not let this worry you; what is unclear at a first reading will become clear at a second reading, or when you subsequently approach the question from a somewhat different angle." He emphasized, "Anybody who desires to study it seriously and master it independently must attack it several times, return to it again and again and consider it from various angles to attain a clear, sound understanding of it." Comrade Mao Zedong stressed that to take a scientific attitude is to seek truth in facts, stating that "The absence of a scientific attitude, that is, the absence of the Marxist-Leninist approach of uniting theory and practice, means that Party spirit is either absent or deficient." The learning methods above are still applicable for how we should study the classical works of Marxism today.

- Leading Officials Must Value the Study of the Classical Works of Marxism-Speech at the Opening Ceremony of the Second Batch of Classes for Advanced Studies at the Central Party School in 2011 Spring Semester (May 13, 2011).

\section{Commentary}

As revolutionary instructors, Marx, Lenin, and Mao Zedong made great efforts in pursuit of truth.

Marx read and wrote all year around. His method of taking a break was simply walking up and down the room, so that there was a trace trod through the carpet from the door to the window in his room, just like a path through the grass. When he was writing Capital, to finish two dozen pages on British labor law, he studied all the blue books in the library that contained the reports of the British and Scottish commissions of investigation and factory inspectors.

Lenin continued to read and write, even when he was in prison. To evade notice by the prison guards, he poured milk into his bread, which he used as makeshift ink. When the milk dried, it became invisible. When a guard came into his cell, he ate the little "ink bottle". Once he wrote in a letter that, "I have eaten six 'ink bottles' today." In Volume 40 of the Collected Works of Vladimir Lenin compiled by the Marxist-Leninist Institute of the CPSU Central Committee, approximately 400 out of the 500 pages are composed of Lenin's comments on, notes to, and excerpts from the works of Marx, Engels, and others. 
Mao Zedong repeatedly read Capital. The People's Publishing House even printed a large-character edition of the work especially for him. He also read The History of the Communist Party of the Soviet Union and Outline of the Sociology by Li Da more than ten times in addition to reading through The Communist Manifesto, Capital, Selected Works of Lenin, Critique of the Gotha Program, The State and Revolution, and other works repeatedly. He also made comments on and put annotations in many chapters and paragraphs. Every time he read a book or an article, he circled, underlined, drew arrows, and other marks at places that he considered important, and he wrote many comments in the margins. When he was dying, three editions of The Communist Manifesto were still laying beside him: a thread-bound large-character edition and two other editions that had been published in wartime.

At the opening ceremony of the second group of classes for advanced studies at the Central Party School in spring semester 2011, Xi Jinping taught the trainees how to address difficulties in reading and understanding original works by introducing the experiences of Marx, Lenin, Mao Zedong, and other revolutionary instructors in "reading original works." As he said, "Officials, especially high-ranking ones, should master the basic theories of Marxism as their special skill and diligently study MarxismLeninism and the thought of Mao Zedong, especially Deng Xiaoping's Theory, the important thought of the Three Represents and the Scientific Outlook on Development."

\section{The Xunwu Investigation}

When Comrade Mao Zedong was conducting an investigation in Xunwu County, he directly convened the people from all sectors and held a factfinding meeting, collecting a great deal of first-hand information, including the yields and prices of all categories of products in the county, the numbers and proportions of employees in various industries in the urban area, the scope of businesses and the incomes of the shops, the land areas and incomes of the peasants in different areas, as well as the political attitudes of all groups of people. He made all of these categories crystal clear. Such an in-depth and pragmatic style is worth attaining. 
- A Talk on Investigation and Study-Speech at the Opening Ceremony of the Second Batch of Classes for Advanced Studies at the Central Party School in 2011 Autumn Semester (November 16, 2011).

\section{Commentary}

The exhibition "The Road to Rejuvenation" at the National Museum of China has on display a precious lithographed book. The book is the Investigation Work written by Mao Zedong in Xunwu County in May 1930. The title was later changed to To Oppose Dogmatism. In the article, Mao Zedong first put forward the idea that "He who makes no investigation has no right to speak" and "The victory of China's revolutionary struggle depends on the Chinese comrades' understanding of the situation in China." The Xunwu investigation, whether in terms of revolutionary guidance or scientific research, is a brilliant example for our Party to carry out investigations.

The Xunwu investigation was the largest scale social investigation initiated by Mao Zedong in the agrarian revolution period, and it was also his first investigation focusing on an urban area. In May 1930, Mao Zedong led the Red Army to march from Huichang to Xunwu, Jiangxi Province. Located at the Jiangxi' border area that neighbors on Guangdong and Fujian provinces, Xunwu was a main distribution center of commodities. In Mao's view, "I have not yet fully understood the rich peasant issue in China, and I am only a layman in commerce, so I must make great efforts to carry out this investigation." Thus, he set out to investigate the commercial state in the urban area of Xunwu when the troops mobilized the people to join the agrarian revolution in the neighboring counties.

"Which tofu shops make the best tofu and sell best in Xunwu? And which shops brew the best wine here?" These were some of the questions Mao Zedong asked before the investigation, which stumped the local officials. The investigation team headed by him visited 47 stores and 94 shops engaged in handicraft. They took part in labor with the masses and communicated with them. Based on this investigation, the Red Army established the urban policy that would "eliminate the exorbitant taxes and protect trade," correct the left-leaning errors and solve the problem of supply shortage. 
The report of this action, the Xunwu Investigation, consisted of five parts: the political division of Xunwu, transportation, commerce, original agrarian relationship, and agrarian struggle. The report provided an overview of the situation of Xunwu through statistical data, an introduction of historical evolution, an industrial survey and class analysis. From the report, we can not only read the 131 imported products being sold in the variety stores in the county and obtain a glimpse of the operation of the shops making jewelry and those repairing clocks and watches but also get a sense of how the rural ancestral hall distributed grain and meat at festivals. Such meticulous material, informational, and scientific analysis and comprehensive study were featured in the report.

"Investigation is the foundation for achievement and the way toward success. He who makes no investigation has no right to speak, and, of course, has no right to make decisions." In his distinctive style, Xi Jinping always attaches great importance to investigation and advocates in-depth and pragmatic investigation. By quoting the instance of the Xunwu investigation initiated by Mao Zedong, he exhorted the officials that, to conduct an investigation, one must go to grassroots communities, find out what the people think and want, and correct their perceptions according to the people's social practices.

Many classes of the Central Party School are required to conduct special investigations. At the opening ceremony of the second group of classes for advanced studies at the Central Party School in the 2011 autumn semester, $\mathrm{Xi}$ Jinping gave the trainees a special lesson on investigation. In the talk, he put forward many important judgments and made some working demands. For instance, investigation is not only a working method but it is also a big problem concerning the success of the Party's and the people's cause; to measure whether an investigation is well done, we should consider the actual effect of the investigation as well as the application of the investigation's results and judge whether the problems have been solved.

\section{The II4-Character EPITAPH}

Comrade Mao Zedong composed an epitaph for the Monument to the People's Heroes in only 114 Chinese characters, which, however, describes the whole modern history of China. In 1975, Comrade Deng Xiaoping drafted the report that was to be made by Premier Zhou Enlai at the first plenary session of the Fourth National People's Congress in only 5,000 characters. Later, when discussing this matter, Deng Xiaoping said, "Chairman Mao 
designated me to head the drafting of the report and limited it to five thousand characters. I finished the task. The 5,000 characters indeed work very well, don't they?"

- Get Rid of the Bad Style of Writing and Promote the Good StyleSpeech at the Opening Ceremony of the Second Batch of Trainees of the Central Party School in 2010 Spring Semester (May 12, 2010).

\section{Commentary}

From September 21 to 30, 1949, the first plenary session of the Chinese People's Political Consultative Conference was held in Peiping (now Beijing). To commemorate the heroes of the people who laid down their lives in the people's war of liberation and the people's revolution, the conference decided to establish the Monument to the People's Heroes outside Tian An Men in China's capital of Beijing. Mao Zedong composed the following epitaph for the monument: Eternal glory to the heroes of the people who laid down their lives in the people's war of liberation and the people's revolution in the past 3 years! Eternal glory to the heroes of the people who laid down their lives in the people's war of liberation and the people's revolution in the past 30 years! Eternal glory to the heroes of the people who from 1840 laid down their lives in the many struggles against domestic and foreign enemies and for national independence and the freedom and well-being of the people! Short although the epitaph is, it is concise and powerful and expresses the admiration for and memory of the people's heroes.

From January 13 to 17, 1975, the first plenary session of the Fourth National People's Congress was held in Beijing. This was the only session of the Fourth National People's Congress held during the Cultural Revolution. In consideration of the physical condition of Zhou Enlai, Premier of the State Council at the time, Deng Xiaoping, then the First Vice Premier, received the commission by Mao Zedong to preside over the drafting of the government's work report on behalf of Zhou Enlai. Not only did Deng compress the report to only 5,000 Chinese characters but he also led the drafting team to overcome all the obstacles and to put Zhou's thoughts about the "Four Modernizations" into the report as a focal point. Once the grand goal of "Four Modernizations" was reported, it immediately raised the confidence of the whole Party and the people to break through the 
shackles of the "Cultural Revolution". Deng Xiaoping thus said, "The five thousand characters indeed work very well, don't they?"

Xi Jinping said, "We should abandon empty talk while advocating short, pragmatic and novel writing styles." This is what Xi Jinping preaches, and it is also what he practices. He employed a simple writing style as early as 1984, when he published his first signed paper, Young and Middle-aged Officials Should Respect the "Veterans" in the People's Daily as the County Party Secretary of Zhengding, Hebei Province. When he served as Provincial Party Secretary of Zhejiang during 2003 and 2007, he published a total of 232 brief comments in the special column "Fresh Ideas of Zhejiang" for the Zhejiang Daily. Composed of only 300 to 500 characters without empty rhetoric or a bureaucratic tone, these works put forward strong viewpoints by quoting the classics, told the truth in an easy-to-understand way, and struck at the heart of the issues. Many of the thoughts and expressions in the articles are still worth considering to this day.

The writing style of an official reflects his or her work style as well as capability and qualification. Hence, Xi Jinping attaches great importance to the issue of writing style. There is a misconception of writing style: the length of an article is proportional to its grade. Xi Jinping cited the 114character epitaph of the Monument to the People's Heroes and the 5,000character government work report drafted by Deng Xiaoping on behalf of Zhou Enlai to prove that a short essay can also contain rich content, and an author should aim at integrating profound meaning in as succinct an article as possible.

$\mathrm{Xi}$ Jinping once quoted an allusion in Chuang Tzu: "What is long is not considered as excess, and what is short is not regarded as wanting. A duck's legs, although short, cannot be lengthened without dismaying the duck, while a crane's legs, although long, cannot be shortened without leaving the crane miserable." This means that although a duck's legs are short, it would bother the duck if they were lengthened; although a crane's legs are long, the crane would suffer if they are shortened. The same is true for writing. He noted that today there are too many articles that look like "the lengthened leg of a duck", and hence advocating for short articles, short speeches, and short files as today's main task in the improvement of one's writing style. 


\section{Read the Communist Manifesto ioo Times}

To study the works of Karl Marx, Vladimir Lenin, and Mao Zedong, we should read them carefully and thoroughly and make real effort in our study. At the end of 1939, Comrade Mao Zedong said to a comrade who was studying in the Marxist-Leninist College that "You must read the books on Marxism-Leninism often. I have read The Communist Manifesto more than one hundred times. Every time I come up against a question, I looked for answer in it. Sometimes I just select one or two paragraphs to read, and sometimes I read the book through. Every time I read it, I receive new inspiration from it. I also referred to it many times while writing $\mathrm{On} \mathrm{New}$ Democracy. Our purpose of reading the Marxist theories is to apply them. And to apply them properly, we must read them repeatedly and carefully." Comrades Deng Xiaoping, Jiang Zemin, and Hu Jintao have all repeatedly stressed the importance of carefully studying original works in different periods.

- Party Officials Should Love Reading, Be Good at Reading, and Read Good Books-Speech at the Opening Ceremony of the Second Batch of Classes for Advanced Studies at the Central Party School in 2009 Spring Semester (May 13, 2009).

\section{Commentary}

The Communist Manifesto is the first programmatic document for the international communist movement, marking the birth of Marxism. Although it is not long, it shocked the whole world as a "spiritual atomic bomb" when it was published. In terms of theory, it is permeated with the basic spirit of historical materialism, providing a scientific methodology for understanding human society. In terms of practice, it served as the party program of the first international communist organization, which included the chanted slogan "Workers of the world, unite!", providing a guide to action for the proletarian revolution. Friedrich Engels noted that The Communist Manifesto "is the most widely dispersed and international book among all Socialist literature" and that it is the first "comprehensive party program covering both theory and practice" for the Proletarian parties all over the world.

The Communist Manifesto also had an extraordinary impact on China's revolution and the CPC. Mao Zedong once revealed to Edgar Snow that 
it was under the influence of The Communist Manifesto that he became a Marxist who preached Marxism and, to a certain extent, practiced it by the summer of 1920. Once at a meeting, Zhou Enlai, who was in his later years, walked up to Mr. Chen Wangdao, the translator of the first Chinese version of The Communist Manifesto, and asked Chen if he could find the first Chinese version because he wanted to have one more look at it. Deng Xiaoping first read The Communist Manifesto when he studied and worked in Paris and then joined the Communist Party and the revolution. "My primer was The Communist Manifesto," he said with deep emotion in his 1992 Southern Tour.

It is not easy for our Party officials to study the original works of Marxism-Leninism. Xi Jinping told Mao Zedong's story of studying The Communist Manifesto with the intention of informing the officials that the pith and marrow of Marxism can be only acquired through diligent study, even for the leaders of our Party. By doing so, he proved the importance of reading original works carefully and increased the officials' confidence in studying the classics. Xi has spoken of The Communist Manifesto on multiple occasions, "Marxism is the 'scripture' for us communists. He who only thinks about 'how to make a pilgrimage', instead of 'studying the scripture', would be misled!"

According to the villagers of Liangjiahe Village, Xi Jinping has read Capital as early as when he worked in the countryside. When he studied for a doctorate at the School of Humanities, Tsinghua University during 1998 and 2002, he majored in Marxist theory and ideological and political education. While heading the drafting of the political report to the 18th National Congress of the CPC, he asked to put these words into the report: "Belief in Marxism and faith in socialism and communism are the political soul of Communists, enabling them to withstand all tests." As he stressed, the officials must fully understand the importance of "studying the theories of Marxism-Leninism in a general and in-depth manner," and they should read the classic Marxist works carefully and thoroughly.

\section{The Three States of Study}

The famous scholar Wang Guowei once described the three states of study with three poetic lines, respectively. The first is "Last night the western breeze blew withered leaves off trees. I mount the tower high and strain my longing eyes"; the second is "I find my gown too large, but I will not regret; it's worthwhile growing languid for my coquette"; and the third is 
"In the crowd once and again I look for her in vain. When all at once I turn my head, I find her there where lantern light is dimly shed." (All the three lines above are translated by Xu Yuanchong.)

We officials must reach these three states in theoretical study. In theoretical study, first, we should aim high, endure loneliness, and settle down to diligently inform ourselves on important works, which can be compared to the line, "mount the tower high and strain my longing eye." Second, we should assiduously and unswervingly and make real and painstaking effort. During this process, we should not regret, although "our gown becomes too large and we grow languid." Third, in study, we should learn to think for ourselves and understand the true essence of theories; in practice, we should apply what we have learned and further grasp the true essence of the readings. We may look for the essence in vain at first; however, we will finally find it when we least expect it. Only in this way can our officials take the lead in studying thoroughly and persistently, and only in this way can they provide fine examples of diligent studying and thinking, fine examples of emancipating the mind and keeping up with times, and fine examples of accomplishing things by applying what one has learned.

- Three States of Theoretical Study (July 13, 2003) From Fresh Ideas of Zhejiang.

\section{Commentary}

The theory of "the three states of study" is derived from a paragraph in Jen-Chien Tz'u-Hua by Wang Guowei, a master in sinology. He said, "Everyone who has achieved great things or is of profound learning has surely reached three states in study. 'Last night the western breeze blew withered leaves off trees. I mount the tower high and strain my longing eye.' This is the first state. 'I find my gown too large, but I will not regret; 'it is worthwhile growing languid for my coquette.' This is the second state. And the third is 'In the crowd once and again I look for her in vain. When all at once I turn my head, I find her there where lantern light is dimly shed'." These lines depicting the three states of study and career are ingenious quotations of the verses of Yan Shu, Liu Yong, and Xin Qiji, which describe romantic scenarios.

The first state derives from the Butterflies in Love with Flowers-Orchids Shed Tears with Doleful Asters in Gray Mist by Yan Shu, a poet of the 
Northern Song Dynasty: "Orchids shed tears with doleful asters in gray mist; silk curtain chill, a pair of swallows fly away. The moon, knowing not parting grief, sheds slanting light through crimson windows all the night. Last night the western breeze blew withered leaves off the trees. I mount the tower high and strain my longing eye. I'll send a message to my dear, but endless ranges and streams serve us far and near." In the first part of this Ci poem, the poet takes advantage of the scene to express the hero's pain of parting. Stemming from such pain, the second part draws a vivid picture that illustrates his lovesickness-“strain his longing eye from the tower high." Wang Guowei expressed his thoughts through this Ci poem: a person engaged in scholarship who aims to achieve great things should first persist in his or her pursuit and look far ahead from a high plane to determine his or her goal, direction, and path.

The second state stems from the Butterflies in Love with Flowers - I Lean on the Balcony in a Light, Light Breeze by Liu Yong, another poet of the Northern Song Dynasty: "I lean on balcony in a light, light breeze; as far as the eye sees, on the horizon's dark parting, grief grows unseen. In fading sunlight smoke rises over grass green. Who understands why mutely on the rails I lean? I'd drown in wine my parting grief; chanting before the cup, strained mirth brings no relief. I find my gown too large, but I will not regret;'it is worthwhile growing languid for my coquette." The theme of this Ci poem is homesickness and lovesickness, emphasizing the hardships of love and the poet's lack of regret. By depicting the scenery, he expresses his feelings of loss and grief far away from home and his yearning for whom he is in love with, enabling readers to sense his sincere affection. Wang Guowei used the two lines in this $\mathrm{Ci}$ poem as a metaphor for the pursuit of great achievements and great learning, which expresses that no one can achieve great things or great learning in the course of a single walk; thus, we must pursue our aims unswervingly and without regret.

The third state stems from the poem Green Jade Table-The Lantern Festival Night by Xin Qiji, a Ci poet of the Southern Song Dynasty: "One night's east wind adorns a thousand trees with flowers and blows down stars in showers. Fine steeds and carved cabs spread fragrance en route; music vibrates from the flute; the moon sheds its full light while fish and dragon lanterns dance all night. In a gold-threaded dress, with moth or willow ornaments, giggling, she melts into the throng with trails of scents. But in the crowd once and again I look for her in vain. When all at once I turn my head, I find her there where lantern light is dimly shed." The first part of this $\mathrm{Ci}$ poem depicts the scene of joy and peace at the lantern show of 
the Lantern Festival, while the second part illustrates that the hero searches for the lady to whom he lost his heart, portraying a subtle beauty without a trace of vanity. Wang Guowei cited this line to exhort us that in the process of study, we cannot gain insight without unremitting exploration and research.

Citing "the three states of study," this talk on theoretical study by $\mathrm{Xi}$ Jinping encouraged learning using beautiful lines to inspire officials to take the lead in studying theoretical knowledge thoroughly and persistently. The theory of "the three states of study" exhorts us that, in theoretical study, first, we should not only aim high, endure loneliness and settle down to diligently study important works but we should also think for ourselves to understand the true essence of theories and apply what we have learned.

\section{Do not Be Pessimistic, or Idle the Time Away}

There is a young man named Zheng Chunlin in the Qiji Group of our county. He has a disability in one leg due to infantile paralysis. Yet he is neither pessimistic nor does he idle the time away. Instead, he went to Beijing and studied painting as well as photography at his own expense, and he then established a mobile painting and photo studio in his hometown to provide door-to-door services to paint screen walls and kang boxes (kang is a type of heatable brick bed that is common in Northern China) and taking photos for the local people. One night a teacher from a nongovernmental school went to his house to have a photo taken for urgent use and requested that the photo should be ready the same day. However, a roll of film must be developed only after it has run out because it can only be developed one time. To fulfill the teacher's urgent need, he developed a single photo for this customer, with the rest of the film being nullified. He cannot perform physical labor because of the disability in the leg, so he started a family business at home. He raised more than 20 minks and voluntarily taught other young people the skill of raising minks, leading more than a dozen families to become employed in this business. Over 2 years, he earned nearly 10,000 yuan, which in 1983 was a lot. He even built the first small building in the Qiji Group with the income he earned. If all the young people in our country could be as selfless and dedicated as he is, and exert their talents to develop their hometown, then Zhengding will soon experience an earth-shaking change. 
- To Vitalize Zhengding, To Be the Young Generation Hardworking and Promising (August 10, 1983), from Know It Deeply, Love It Deeply.

\section{Commentary}

It is said that "A fine example excels twenty instructions from books." The example is the driving force of progress. Having a disability in one leg due to infantile paralysis, Zheng Chunling did not abandon himself to despair but studied painting as well as photography at his own expense and acquired wealth by raising minks, after which he even led other villagers to earn money through this family business. With an extraordinary desire to advance and his executive ability, he set an extraordinary example of alleviating poverty and helping fellow villagers. Even to this day, his story serves as a stimulus to encourage people to advance, which makes him an inspiration for us all.

In August 1983, Xi Jinping, who at the time served as County Party Secretary of Zhengding, stated that "The youth are the most active and vigorous force in society as a whole. They are those on whom we will depend to vitalize Zhengding." He also described some of the weaknesses and shortcomings of some young people. For example, some of them "do not have the ability to do what they hope to do" or "blindly perceive that they are inferior." He went on to say that "Some of them just want to pick the roses in the distance as they tread on those that grow underfoot. They forget that to achieve great things, we must start from minor matters and get involved with what is right in front of us." In his view, if the youth look down on the grassroots work and ordinary posts, and if they idle their time away daydreaming about "great achievements" instead of completing the immediate tasks at hand, then none of their dreams will come true. Therefore, in his speech, he shared Zheng Chunlin's story of starting a business and helping his fellow villagers get rich. He encouraged the youth of Zhengding to concentrate on their own duties and work hard, and he exhorted them to head toward their bright futures by starting with minor matters.

In the speech "To Vitalize Zhengding, To Be the Young Generation that is Hardworking and Promising," he also shared another inspirational story. 
Huang Chunsheng, who was of a low degree of education, began to cultivate an improved variety of cotton in 1969. Lacking the relevant knowledge, he started learning from scratch. He studied the units on plants in middle-school textbooks. Then, he taught himself with the relevant teaching materials from Hebei Normal University and Hebei University and read a number of journals about agricultural science and technology. He even made special trips to universities, colleges, and research institutions to consult experts and professors. After several years of hard work and assiduous study, the cotton variety "Jimian 2" cultivated by him won second prize for scientific and technological achievements of Hebei Province and covered a planting area of nearly 66,666 hectares all over our country. In view of his achievements, he was praised as the "self-taught expert" in cotton breeding.

$\mathrm{Xi}$ Jinping told Zheng Chunlin's story to teach the youth that only if they perform their duties in a down-to-earth manner and strive for excellent performance in their own posts can the wisdom and talents of all young people be integrated into a tremendous force to advance the development of society as a whole. As long as they concentrate on their own duties and work hard on minor matters, they will certainly have a bright future. We can recognize this truth in Zheng Chunlin's story.

Time and again, Xi Jinping has encouraged the youth to seek out experience in grassroots work. He wrote to the college-graduate village official Zhang Guangxiu and expressed his ardent expectation of all collegegraduate village officials, emphasizing that they should "love and take root in grassroots communities; open their minds and enhance their abilities in grassroots posts; and aim to promote rural development, bring benefit to peasants and enjoy a youth without regret." In his letter in reply to a Benyu Volunteer Team from Huazhong Agricultural University, he also encouraged the young generation to insist on advancing together with the motherland and devoting themselves to the cause of the people, and he inspired them to make greater contributions to the realization of the Chinese dream on the basis of their youthful dreams and through their actions.

\section{The Return of a Prodigal Child}

Here is another story about the return of a prodigal child. Zhou Chu was a famous prodigal son in Chinese history. When he was young, he had surprising strength and a fiery temper, and he liked riding horses and hunting with a bow and arrow. He often harassed and mistreated the local people. 
At that time, a fierce tiger on the southern mountain and an alligator in the river often hurt the people; thus, the fierce tiger, the alligator, and Zhou Chu were collectively referred to as "the three pests" by the locals. Later, Zhou Chu rectified his errors by thoroughly following the instructions of the famous scholar Lu Yun. He not only rushed to kill the tiger on the mountain and the alligator in the river but he also became erudite and cultured by studying diligently. In the end, he died a glorious death for his state in battle. This shows that to err is human. One is a good person if he corrects his error quickly. This corroborates the old saying: "A prodigal who returns is more precious than gold."

- Talents Play an Immeasurable Role in Economic Development (April 25, 1983), from Know It Deeply, Love It Deeply.

\section{Commentary}

Zhou Chu was a brave warrior in the late Three Kingdoms Period and the Western Jin Dynasty. He was "of extraordinary strength" when he was young; however, he had a bad reputation in his hometown because "he paid no attention to small matters and did just as he pleased without restraint." The local people referred to him as well as the fiery tiger in the southern mountain and the alligator in the river collectively as "the three pests," and Zhou was regarded as the "top pest." Realizing that he himself was disreputable, Zhou made a resolution to correct his errors. So, he went to $\mathrm{Wu}$ Prefecture to ask for advice from the Lu brothers- $\mathrm{Lu}$ Ji and Lu Yun. Unfortunately, Lu Ji was away. However, Lu Yun enlightened him, saying, "The ancients highly valued the practice of correcting mistakes quickly. You are promising, and what is more important for a person is to have an ambition. As long as you are ambitious, you will certainly enjoy a widespread good reputation." As a result, with a guilty conscience, Zhou Chu corrected his mistakes and consequently became a celebrated scholar due to his diligent study. Later, he was sent to the northeast to suppress the rebellion of the Di and Qiang nationalities, and he finally died in battle because his troops were hopelessly outnumbered. He was praised as "a loyal officer of great virtue and loyalty and a martyr of great moral integrity."

The anecdote about Zhou Chu and the return of a prodigal was widely spread. We can read about "Zhou Chu eliminating the three pests" in both the Book of Jin and A New Account of the Tales of the World. There 
is also a contemporary Beijing opera titled "Eliminate the Three Pests". Although Zhou Chu's deeds are said to be somewhat fictitious, the story of "Zhou Chu eliminating the three pests" has the specific cultural function of guiding values and advocating self-cultivation. It has been said that "A gentleman's error is like an eclipse of the sun or the moon. When he errs, all people give attention to him, while when he corrects it, all people look up to him." As in this saying in The Analects, a human being is bound to make mistakes; as long as he corrects his mistakes, he is worthy of praise and admiration.

There is another story about correcting mistakes in the chapter titled "Amender" of A New Account of the Tales of the World. Dai Yuan was engaged in plundering from trade caravans. Lu Ji tried to persuade him away from evil, saying, "You are so talented. But why are you a plunderer?" Following Lu's advice, Dai broke away from the evil path and turned over a new leaf, and he later became a general who subdued the west.

In March 1983, Zhengding County, Heibei Province developed the Nine Measures for Establishing a New View of Talent Employment for the New Period and Recruiting Talented People. However, in the process of carrying out the measures, some Party officials did not obtain a full understanding of "recruiting talented people," and some were skeptical about or took a wait-and-see attitude toward the measures. In April of the same year, Xi Jinping highlighted the importance of talent at a county, township, and village official meeting with the theme of "vitalize the economy with open policies." He asked leaders at all levels and all officials to establish a new view of talent employment, to implement the nine measures conscientiously and to vigorously seek and attract talents, to vitalize the economy of the county.

$\mathrm{Xi}$ Jinping told Zhou Chu's story to emphasize that "To err is human. One is a good person if he corrects his error quickly." For those who have made mistakes, we should not ignore their virtues while judging those mistakes, and we should notice their advantages and strong points while analyzing their disadvantages and shortcomings. Quoting the old saying "We should highly value a person's morality and forgive him his harmless errors, and we cannot expect anyone to be perfect," he exhorted the officials to emancipate their minds, break through the stereotypes, and eliminate prejudice to appoint people on their merits and acquire talented people through different channels and by different methods. 
Open Access This chapter is licensed under the terms of the Creative Commons Attribution-NonCommercial-NoDerivatives 4.0 International License (http:// creativecommons.org/licenses/by-nc-nd/4.0/), which permits any noncommercial use, sharing, distribution and reproduction in any medium or format, as long as you give appropriate credit to the original author(s) and the source, provide a link to the Creative Commons license and indicate if you modified the licensed material. You do not have permission under this license to share adapted material derived from this chapter or parts of it.

The images or other third party material in this chapter are included in the chapter's Creative Commons license, unless indicated otherwise in a credit line to the material. If material is not included in the chapter's Creative Commons license and your intended use is not permitted by statutory regulation or exceeds the permitted use, you will need to obtain permission directly from the copyright holder.

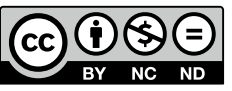

